\title{
Analisis Dimensi Kualitas Pelayanan pada Perusahaan Jasa Pelabuhan Curah PT. Krakatau Bandar Samudera Cilegon Menggunakan Metoda Servqual
}

\author{
Ali Subhan \\ Program Studi Teknik Industri Universitas Suryakancana \\ Jl. Pasir Gede Raya Cianjur, Jawa Barat 43216 \\ E-mail : alisubhan72@yahoo.com
}

Dikirimkan: 08, 2018. Diterima: 09, 2018. Dipublikasikan: 10,2018.

\begin{abstract}
PT. Krakatau Bandar Samudera (Cigading Port) is one of the port services companies that specifically conduct loading and unloading of bulk goods. The current change in the port services industry in the world today has improved the function of the port which not only functions as a transportation chain, but also develops into a service center that functions as a trade logistic platform. This study aims to analyze the dimensions of port service quality in an effort to improve and improve the quality of existing services. The method used in this research is the Service Quality (Servqual method) quantitative measurement model and Gap Analysis. The results showed that of the 5 service quality dimensions divided into 30 service service attributes, there were 20 attributes that were considered important by consumers based on. Based on Gap 5 analysis there are 11 service attributes that have a gap between consumer expectations and consumer perceptions, while based on Gap 1 analysis there are 7 service attributes that have a gap between consumer exposure and management perceptions. On average, the consumer satisfaction index (Customer Satisfaction Index) can be said to be quite good because it has a value of 95.27\%. However, because there are still service attribute variables that have CSI values with the "less" category, there needs to be an even level of improvement in service quality in service attributes that are still lacking.
\end{abstract}

Key words: Service Quality, Servqual Score, Gap Analysis, Customer Satisfaction Index

\begin{abstract}
Abstrak- PT. Krakatau Bandar Samudera (Pelabuhan Cigading) adalah salah satu perusahaan jasa pelabuhan yang khusus melakukan bongkar muat barang-barang berbentuk curah. Adanya arus perubahan dalam industri jasa pelabuhan di dunia saat ini telah meningkatkan fungsi pelabuhan yang tidak hanya berfungsi sebagai mata rantai transportasi, tetapi juga berkembang menjadi pusat pelayanan yang berfungsi sebagai trade logistic platform. Penelitian ini bertujuan untuk menganalisis dimensi-dimensi kualitas jasa pelabuhan dalam upaya memperbaiki dan meningkatkan kualitas pelayanan yang sudah ada. Metoda yang digunakan dalam penelitian ini adalah model pengukuran kuantitatif Service Quality (Servqual method) dan Analisis Kesenjangan (Gap Analysis). Hasil penelitian menunjukkan bahwa dari 5 dimensi kualitas jasa yang terbagi kedalam 30 atribut jasa pelayanan, terdapat 20 atribut yang dianggap penting oleh konsumen berdasarkan. Berdasarkan analisis Gap 5 terdapat 11 atribut pelayanan yang memiliki kesenjangan antara harapan konsumen dengan persepsi konsumen, sedangkan berdasarkan analisis Gap 1 terdapat 7 atribut pelayanan yang memiliki kesenjangan antara haparan konsumen dengan persepsi manajemen. Secara rata-rata indeks kepuasan konsumen (Customer Satisfaction Index) bisa dikatakan cukup baik karena memiliki nilai sebesar 95,27\%. Namun demikian, karena masih terdapat variabel-varibel atribut pelayanan yang memiliki nilai CSI dengan kategori "kurang", maka perlu ada pemerataan tingkat perbaikan kualitas pelayanan pada atribut pelayanan yang masih dirasakan kurang.
\end{abstract}

Kata Kunci: Kualitas Jasa, Servqual Score, Gap Analysis, Customer Satisfaction Index

perubahan yang cepat dari permintaan, keinginan serta kebutuhan pelanggan akan

\section{PENDAHULUAN}

Persaingan bisnis pelabuhan semakin kompetitif seiring dengan perkembangan dan jasa pelabuhan. Hal ini memotivasi perusahaan jasa pelabuhan untuk terus 


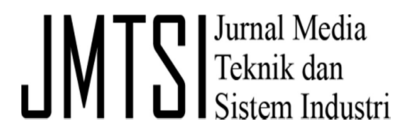

memperbaiki dan meningkatkan kualitas pelayanannya.

Pelabuhan berfungsi sebagai tempat berlabuhnya kapal-kapal yang merupakan suatu tempat berlindung dari gangguan laut, sehingga bongkar muat dapat dilaksanakan untuk menjamin keamanan barang maupun penumpang [1]. Untuk dapat bersaing di pasar global pelabuhan sebagai salah satu produk jasa perlu memperhatikan kualitas pelayanan terhadap konsumen pengguna jasa pelabuhan. Adanya arus perubahan dalam industri jasa pelabuhan di dunia saat ini telah meningkatkan fungsi pelabuhan yang tidak hanya berfungsi sebagai mata rantai transportasi, tetapi juga berkembang menjadi pusat pelayanan yang mampu menawarkan paket pelayanan komprehensif dan berfungsi sebagai trade logistic platform yang mampu memberikan nilai tambah bagi konsumen pengguna jasa pelabuhan. Perubahan fungsi pelabuhan tersebut mendorong PT. Krakatau Bandar Samudera untuk melakukan pengembangan pola operasi dan pola pelayanan pelabuhan, sehingga para pengguna jasa pelabuhan (port user) menjadi lebih terjamin baik segi waktu maupun kualitas pelayanan.

Dalam perkembangannya PT. Krakatau Bandar Samudera tidak hanya melayani keperluan kargo PT. Krakatau Steel sebagai pengangkut bijih besi dan hasil industri baja saja, tetapi juga melayani kargo lain seperti pelet, batubara, gipsum, pupuk, besi tua, kedelai, bungkil, jagung, garam, dan gula. Saat ini Pelabuhan Cigading berkonsentrasi pada bisnis kargo curah, dengan visinya "Menjadi Pelabuhan Curah Kelas Dunia". Berbagai jenis jasa layanan yang disediakan oleh PT. Krakatau Bandar Samudera antara lain jasa penyediaan kolam labuh, jasa penyediaan dermaga untuk sandar, jasa bongkar muat (loading/unloading service), jasa pergudangan baik terbuka maupun tertutup, jasa workshop, alat berat dan alat bongkar muat, jasa handling/processing (bagging) dan transportasi, jasa penyediaan bahan untuk industri dan distribusi dan jasa logistik \& transhipment.

Penelitian ini bertujuan untuk mengidentifikasi atribut-atribut pelayanan apa saja yang sudah disediakan oleh PT.
Krakatau Bandar Samudera, selanjutnya mengetahui sejauhmana kualitas pelayanan yang telah diberikan oleh pelabuhan PT. Krakatau Bandar Samudera, dan bagaimana merumuskan langkah-langkah strategis yang harus dilakukan PT. Krakatau Bandar Samudera dalam upaya memuaskan pelanggan.

\section{Metodologi Penelitian}

Ditinjau dari terminologinya, sistem transportasi dari suatu wilayah adalah sistem pergerakan manusia atau barang dari satu zona asal (origin) ke satu zona tujuan (destination) dalam wilayah yang bersangkutan. Pergerakan yang dimaksud dapat dilakukan dengan menggunakan berbagai sumber tenaga dan dilakukan untuk suatu tujuan tertentu [2].

Perkembangan angkutan sesuai dengan temuan teknologi baru, berkembang dalam bentuk jasa angkutan darat, laut dan udara. Dengan terjalinnya daerah-daerah tersebut dalam jaringan jasa angkutan, nilai ekonomis suatu jenis barang menjadi naik di tempat tujuannya, dengan demikian timbul suatu motivasi untuk mendapatkan keuntungan yang berarti pula mendorong pertumbuhan ekonomi daerah dan masyarakat di regional tersebut. Sesuai dengan perkembangan kebudayaan dan teknologi, perpindahan muatan (barang-barang) ini membutuhkan dimensi baru, yaitu segi kualitas produk jasa angkutan yang meliputi keamanan muatan, kecepatan, dan ketepatan akan tibanya ditempat tujuan, dan keteraturan singgah dari sarana angkutan (frekuensi) tersebut.

Dari segi operasional, pengusahaan pelabuhan harus menyediakan prasarana yang diperlukan bagi kapal dan barang untuk mendukung kelancaran arusnya. Penyediaan fasilitas pelabuhan yang berlebihan akan menguntungkan pemakaian jasa, tetapi di lain pihak memberatkan pengusahaan pelabuhan. Sebaliknya penyediaan fasilitas yang kurang akan menguntungkan pengusahaan pelabuhan, tetapi merugikan penyediaan jasa, kurang melancarkan arus barang dan kapal serta makin berakibat lebih luas yaitu tidak dapat mendukung pengembangan sektorsektor ekonomi lainnya dan pada akhirnya 
akan merugikan masyarakat secara keseluruhan [1].

Jasa adalah setiap kegiatan atau manfaat yang dapat diberikan oleh satu pihak pada pihak lainnya, yang pada dasarnya tidak berwujud dan tidak pula berakibat pemilikan sesuatu. Produksinya dapat berhubungan dengan produk fisik ataupun tidak [3].

Pengukuran kualitas jasa tampaknya sulit dilakukan karena menyangkut karakteristik jasa yang khas yaitu sifat intangibility (tidak berwujud), heterogenity (keberagaman), inseparability (tidak dapat dipisahkan), dan perishability (tidak dapat bertahan lama). Secara konseptual, kualitas jasa didefinisikan sebagai keputusan global atau sikap yang berhubungan dengan seluruh keunggulan atau superioritas dari pelayanan [4]. Penelitian selanjutnya [5], berhasil meringkas model 10 dimensi tersebut menjadi model 5 dimensi dengan 22 item pertanyaan.yang terdiri dari dimensi kualitas jasa sebagai berikut:

1. Berwujud (tangible)

Adalah penampilan fasilitas fisik, peralatan, personil dan media komunikasi.

2. Keandalan (reliability)

Adalah kemampuan untuk menampilkan pelayanan (melaksanakan jasa) yang dijanjikan dengan tepat dan terpercaya.

3. Daya Tanggap (responsiveness)

Adalah keinginan untuk membantu pelanggan dan memberikan pelayanan yang cepat.

4. Keyakinan (confidence)

Adalah pengetahuan dan kesopanan serta kemampuan mereka untuk menimbulkan kepercayaan dan keyakinan atau "assurance".

5. Empati (empathy)

Adalah syarat untuk peduli, memberi perhatian pribadi bagi pelanggan.

Kelima dimensi kualitas jasa tersebut di atas merupakan hasil penelitian [5], yang dikenal dengan model Service Quality (SERVQUAL) seperti terlihat pada gambar 1.

Data-data yang dikumpulkan dalam penelitian ini berupa data primer dan data sekunder. Data primer diperoleh dengan melakukan wawancara langsung dengan manajemen pelabuhan dan penyebaran kuesioner kepada 75 responden perusahaan pengguna jasa pelabuhan PT. Krakatau Bandar Samudera. Jumlah 75 responden merupakan hasil perhitungan kecukupan sampel. Data sekunder diperoleh dari bukubuku pedoman, brosur-brosur, dan booklet yang dimiliki perusahaan. Hasil pengumpulan data kuesioner yang disebarkan ke sejumlah responden selanjutnya dilakukan uji validitas dan uji reliabilitas.

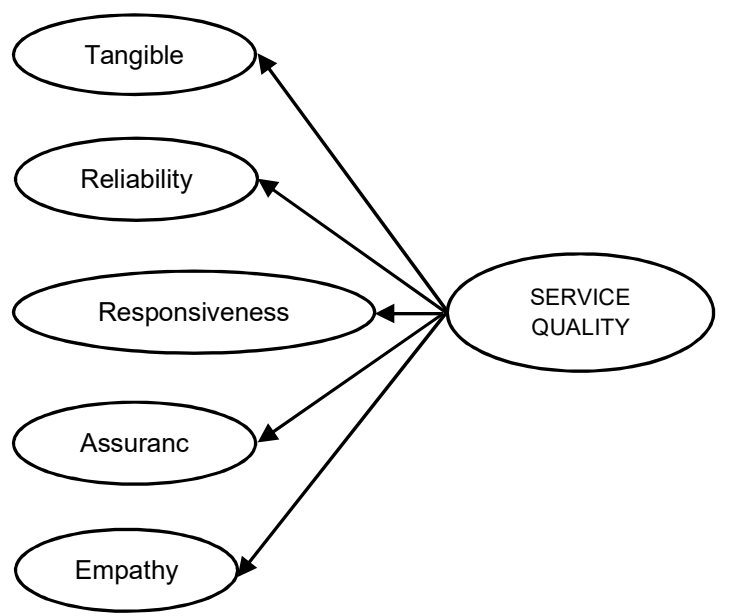

Gambar 1. Model Service Quality

Model yang dikembangkan dalam penelitian ini adalah model kualitas jasa [5] yang berupa lima dimensi kualitas jasa dengan teknik pengukuran menggunakan skala Likert. Hasil kombinasi model ini akan menggambarkan seberapa besar tingkat kepuasan konsumen terhadap kualitas jasa yang diberikan oleh operator pelabuhan. Dalam tahap pengembangan model terlebih dahulu dilakukan survei lapangan dan studi pendahuluan tentang gambaran sistem operasi pelabuhan, sehingga apa yang diinginkan dan dibutuhkan oleh konsumen pengguna jasa pelabuhan dapat diketahui. Metoda analisis yang digunakan pada penelitian ini adalah metoda statistik kuantitatif yang terdiri dari servqual method, analisis gap 5 dan gap 1, analisis diagram kepuasan dan harapan, dan analisis indeks kepuasan pelanggan (Customer Satisfaction 


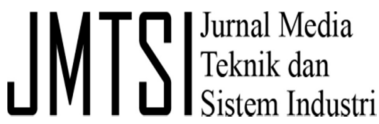

Index). Secara garis besar metodologi penelitian diperlihatkan pada gambar 2 .

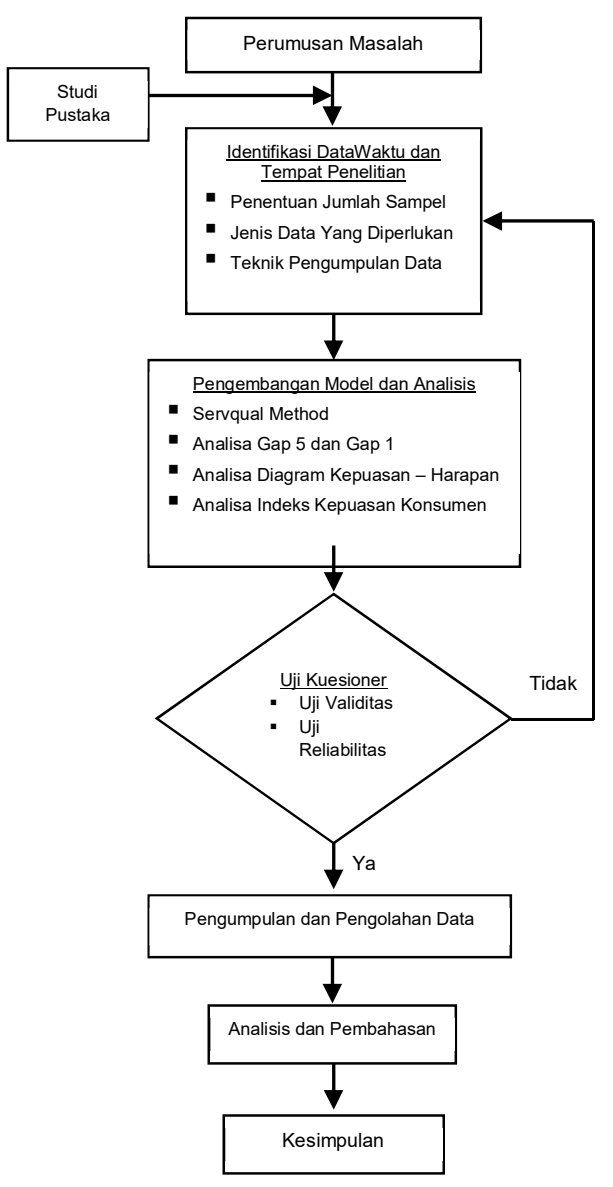

Gambar 2. Metodologi Penelitian

\section{Hasil PENELITIAN DAN PEMBahasan}

\subsection{Uji Validitas dan Reliabilitas}

Berdasarkan hasil uji validitas kuesioner pada tabel 1 dapat diketahui bahwa semua butir pertanyaan pada keempat kelompok kuesioner yang digunakan dalam penelitian ini dinyatakan valid karena memiliki nilai Total Pearson Correlation ( $\mathrm{r}_{\text {hitung }}$ ) lebih besar dari $\mathrm{r}_{\text {tabel }}=0,227$ pada tingkat signifikansi $<0.05$.

Hasil uji reliabilitas menunjukan bahwa keempat kelompok kuesioner yang digunakan dapat dikatakan reliable karena kesemuanya memiliki Standardized Item Alpha diatas 0.7.

\subsection{Analisis Gap 5 dan Gap 1}

Dengan metoda successive interval dapat dihitung skor nilai dari masing-masing atribut harapan konsumen, persepsi konsumen dan persepsi manajemen terhadap pelayanan jasa pelabuhan PT. Krakatau Bandar Samudera. Selanjutnya untuk mengukur seberapa besar gap yang terjadi antara harapan konsumen dengan persepsi konsumen (Gap 5) maka dapat dihitung dengan membandingkan nilai skor atribut harapan konsumen dan atribut persepsi konsumen. Sedangkan untuk mengukur seberapa besar gap yang terjadi antara harapan konsumen dengan persepsi manajemen (Gap 1) maka dapat dihitung dengan membandingkan nilai skor atribut harapan konsumen dan atribut persepsi manajemen. Nilai gap ini didapat dari selisih antara kedua nilai tersebut. Dari hasil perhitungan nilai kesenjangan selanjutnya dapat dihitung indeks kepuasan pelanggan (Customer Satisfaction Index) untuk masingmasing varibel (atribut pelayanan) secara keseluruhan. Hasil perhitungan Gap 5 dan Gap 1 dan CSI secara lengkap dapat dilihat pada Lampiran.

Untuk menganalisa Gap 5 dilakukan penggolongan berdasarkan hasil nilai kesenjangan (SERVQUAL Score). Penggolongan ini dibedakan menjadi 2 bagian, yaitu:

1. Atribut-atribut dengan kategori sangat tinggi sampai dengan tinggi, yaitu atribut-atribut jasa pelayanan pelabuhan yang diberikan oleh PT. Krakatau Bandar Samudera lebih baik atau lebih tinggi dari yang diharapkan oleh konsumennya, sehingga kepuasan yang dirasakan oleh konsumen lebih tinggi dari harapannya. Atribut-atribut dengan kategori sangat tinggi sampai dengan tinggi ini ditunjukkan dengan hurup cetak miring pada kolom Gap 5 pada tabel 3.

2. Atribut-atribut dengan kategori rendah sampai dengan sangat rendah, yaitu atribut-atribut jasa pelayanan pelabuhan yang diberikan oleh PT. Krakatau Bandar Samudera lebih buruk atau lebih rendah dari yang diharapkan oleh konsumennya, sehingga kepuasan yang dirasakan oleh 
konsumen berada dibawah harapannya. Atribut-atribut dengan kategori rendah sampai dengan sangat rendah ini ditunjukkan dengan hurup cetak tebal pada kolom Gap 5 tabel 3.

Dengan membandingkan jumlah atribut kategori 1 dan kategori 2 pada tabel 3, maka dapat diketahui bahwa secara keseluruhan jumlah atribut yang memiliki nilai sangat tinggi s/d tinggi lebih banyak dibandingkan dengan jumlah atribut yang memiliki nilai rendah $\mathrm{s} / \mathrm{d}$ sangat rendah. Namun demikian atribut yang memiliki nilai rendah s/d sangat rendah pada analisa Gap 5 ini juga merupakan hal yang krusial yang menuntut pihak manajemen untuk melakukan proses perbaikan dan peningkatan pelayanan. Grafik Kesenjangan (Gap 5) dapat dilihat pada gambar 3 di bawah ini.

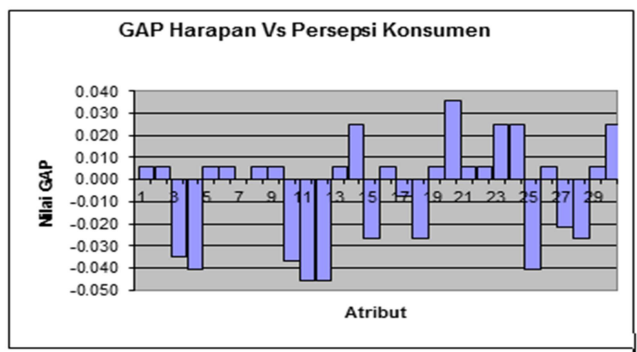

Gambar 3. Kesenjangan (GAP 5) Harapan dengan Persepsi Konsumen terhadap Pelayanan Jasa Pelabuhan PT. KBS

Sama halnya dengan analisa Gap 5 maka untuk menganalisa Gap 1 juga dilakukan penggolongan hasil nilai kesenjangan (SERVQUAL Score) berdasarkan dua bagian, yaitu:

1. Atribut-atribut dengan kategori sangat penting sampai dengan penting, yaitu atribut-atribut jasa pelayanan pelabuhan yang menggambarkan sejauh mana pihak manajemen dan operasional tanggap terhadap pelayanan yang diharapkan oleh konsumennya, sehingga kepuasan yang dirasakan oleh pelanggan lebih tinggi dari harapannya. Atribut-atribut dengan kategori ini dapat ditentukan dengan melihat nilai kesenjangannya, yaitu atribut dengan nilai kesenjangan positif. Atribut-atribut dengan kategori sangat senting sampai dengan penting ini ditunjukkan dengan hurup cetak tebal pada kolom Gap 1 tabel 3.

2. Atribut-atribut dengan kategori tidak penting sampai dengan sangat tidak penting, yaitu atribut-atribut jasa pelayanan pelabuhan yang menggambarkan ketidakpekaan manajemen PT. KBS dalam memenuhi kebutuhan yang diharapkan oleh konsumennya sehingga kepuasan yang dirasakan konsumen dibawah harapannya. Atribut-atribut dengan kategori ini dapat ditentukan dengan melihat nilai kesenjangannya, yaitu atribut dengan nilai kesenjangan negatif. Atribut-atribut dengan kategori tidak penting sampai dengan penting ini ditunjukkan dengan hurup cetak tebal pada kolom Gap 1 tabel 3.

Dengan membandingkan jumlah atribut kategori 1 dan kategori 2 pada tabel 3, maka dapat diketahui bahwa secara keseluruhan jumlah atribut yang memiliki nilai sangat penting s/d penting lebih banyak dibandingkan dengan jumlah atribut yang memiliki nilai tidak penting s/d sangat tidak penting. Hal ini menunjukkan bahwa ketanggapan/kepekaan pihak manajemen lebih banyak memuaskan konsumennya. Namun demikian atribut yang memiliki nilai tidak penting $\mathrm{s} / \mathrm{d}$ sangat tidak penting pada analisa Gap 1 ini juga merupakan hal yang krusial yang menuntut pihak manajemen untuk melakukan proses perbaikan dan peningkatan pelayanan. Grafik Kesenjangan (Gap 1) dapat dilihat pada gambar 4.

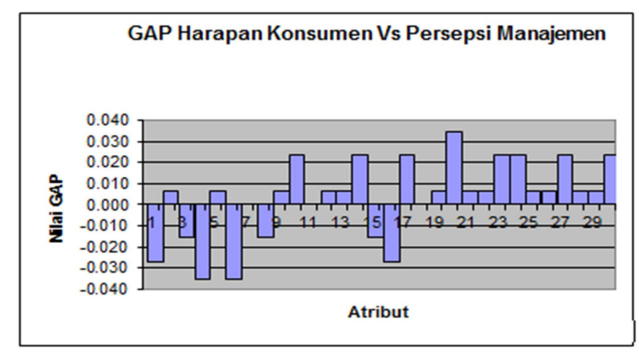


Gambar 4. Kesenjangan (GAP 1) Harapan Konsumen dengan Persepsi Manajemen dalam Pelayanan Jasa Pelabuhan PT. KBS

Dari hasil perhitungan nilai kesenjangan selanjutnya dapat dihitung indeks kepuasan konsumen (consumen satisfaction index) untuk masing-masing varibel (atribut pelayanan) secara keseluruhan. Hasil perhitungan indeks kepuasan konsumen diperlihatkan pada lampiran.

Dari tabel pada lampiran dapat diketahui bahwa rata-rata indeks kepuasan pelanggan secara keseluruhan adalah sebesar 95.27\%. Indeks kepuasan ini menunjukkan bahwa secara rata-rata pelayanan jasa pelabuhan yang diberikan oleh Pelabuhan Cigading (PT. Krakatau Bandar Samudera) sudah maksimal (tinggi). Namun demikian terlihat adanya ketidakmerataan antara nilai indeks kepuasan konsumen atribut yang satu dengan yang lainnya, ada yang kurang dan ada yang berlebihan.

\subsection{Pemetaan Diagram Kepuasaan}

Diagram kartesius menggambarkan pemisahan dimensi SERVQUAL yang terdiri atas empat bagian (kuadran), yang dibatasi oleh garis lurus yang berpotongan pada titik ( $\overline{\bar{X}}, \overline{\bar{Y}}$ ) dimana:

$\overline{\bar{X}}=$ merupakan rata-rata dari nilai skor seluruh atribut kepuasan konsumen

$\overline{\bar{Y}}=$ merupakan rata-rata dari nilai skor seluruh atribut harapan konsumen

Dari hasil perhitungan diperoleh titik perpotongan pada diagram kartesius yaitu $(0,069 ; 0,071)$. Selanjutnya dari diagram kartesius diperoleh hasil pemetaan untuk masing-masing atribut yang disajikan pada gambar 5 dan tabel 1.

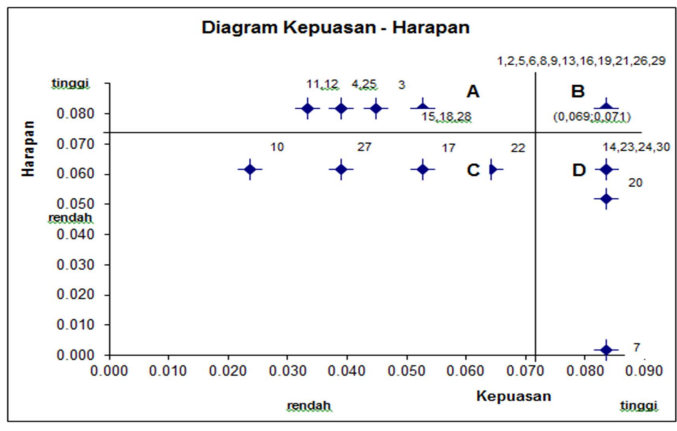

Gambar 5. Diagram Kepuasan - Harapan TABEL I

HASIL PEMETAAN DIAGRAM KEPUASAN-HARAPAN

\begin{tabular}{|c|c|}
\hline Kuadran & Atribut \\
\hline \hline A & $3,4,11,12,15,18,25,28$ \\
\hline B & $1,2,5,6,8,9,13,16,19$ \\
& $21,26,29$ \\
\hline C & $10,17,22,27$ \\
\hline D & $7,14,20,23,24,30$ \\
\hline
\end{tabular}

Berikut ini adalah uraian dari hasil pemetaan diagram kartesius kepuasan - harapan:

1. Atribut yang berada pada kuadran A adalah:

- Ketersediaan penerangan yang cukup di area pelabuhan (tangibles)

- Kebersihan dan keasrian yang terjaga di sekitar dermaga (tangibles)

- Ketersediaan rambu-rambu di area pelabuhan (tangibles)

- Ketersediaan sistem keamanan pelabuhan yang canggih dan modern (tangibles)

- Ketersediaan penerangan lingkungan gudang yang cukup (tangibles)

- Penetapan perkiraan waktu yang diperlukan untuk sampainya barang ke konsumen (reliability)

- Penerbitan Invoice (Tagihan) yang relatif cepat (responsive)

- Jaminan keamanan barang mulai dari dermaga sampai gudang tujuan (assurance)

Atribut-atribut yang terdapat pada kuadran A ini perlu diperhatikan secara khusus untuk mendapatkan prioritas utama dalam perbaikan kualitas pelayanan. Hal ini dikarenakan atribut yang terdapat pada kuadran A dianggap sangat penting oleh konsumen tetapi 
tidak dipenuhi secara maksimal oleh pihak manajemen.

2. Atribut yang berada pada kuadran B adalah:

- Ketersediaan sistem informasi terpadu untuk pembuatan PPJ (tangibles)

- Ketersediaan alur masuk pelabuhan dan sistem sarana navigasi pelayaran (tangibles)

- Ketersediaan kedalaman laut yang memadai untuk bersandarnya kapal besar (tangibles)

- Ketersediaan tambatan yang memadai untuk bersandarnya kapal (tangibles)

- Kondisi alat bongkar muat (crane, grabber, ship unloader dan sebagainya) yang handal (tangibles)

- Ketersediaan area parkir kendaraan bongkar muat barang di pelabuhan yang luas (tangibles)

- Ketersediaan aksesibilitas (jaringan transportasi) ke pengangkutan darat (tangibles)

- Ketersediaan gudang dan kawasan yang luas (tangibles)

- Pengaturan dan pengarsipan data yang baik (reliability)

- Kecepatan waktu bongkar muat barang yang tinggi (reliability)

- Ketersediaan SDM yang memiliki kemampuan kerja yang handal (assurance)

- Keramahan dan kesopanan sikap pelayanan staf administrasi (empathy)

Atribut-atribut yang terdapat pada kuadran B ini pelayanannya perlu dipertahankan dengan baik, karena atribut ini dianggap penting oleh konsumen dan manajemen telah melakukan pelayanan atribut ini secara baik (maksimal).

3. Atribut yang berada pada kuadran $\mathrm{C}$ adalah:

- Jumlah personil bagging yang cukup (tangibles)

- Kemudahan transaksi (pembuatan PPJ) (reliability)

- Penanganan cleaning tumpahan barang curah untuk mengurangi susut (reliability)
- Jaminan terhadap resiko kecelakaan kapal yang berlabuh (assurance)

Atribut-atribut yang terdapat pada kuadran $\mathrm{C}$ ini memiliki prioritas yang rendah menurut kebutuhan konsumen, tetapi ini bukan berarti bahwa atribut tersebut tidak penting/tidak dibutuhkan. Atribut pada kuadran C cukup tetapi bukan menjadi keinginan utama konsumen.

4. Atribut yang berada pada kuadran D adalah:

- Ketersediaan kapal pandu seperti tagboat untuk melakukan ship handling (tangibles)

- Kondisi gudang tertutup yang bersih dan terlindung dari cuaca (tangibles)

- Kemampuan prasarana pelabuhan untuk jaringan pelayaran dalam dan luar negeri (reliability)

- Kemampuan melakukan kalibrasi alat timbangan sebelum dilakukan penimbangan (reliability)

- Kecepatan dalam menanggapi keluhan yang disampaikan oleh pelanggan (responsive)

- Koordinasi yang baik antara staf administrasi dengan customer (empathy)

Atribut-atribut pada kuadran D merupakan atribut yang sudah mendapatkan pelayanan yang "lebih" dari perusahaan, padahal atribut ini tidak terlalu dianggap penting oleh konsumen.

\section{KESIMPULAN}

1. Berdasarkan hasil analisis diagram kartesius kepuasan dan harapan pelanggan terdapat 20 variabel kualitas pelayanan jasa pelabuhan yang dianggap penting oleh konsumen, yaitu variabel $\mathrm{X} 1, \mathrm{X} 2, \mathrm{X} 3, \mathrm{X} 4, \mathrm{X} 5, \mathrm{X} 6, \mathrm{X} 8, \mathrm{X} 9, \mathrm{X} 11$, $\mathrm{X} 12, \mathrm{X} 13, \mathrm{X} 15, \mathrm{X} 16, \mathrm{X} 18, \mathrm{X} 19, \mathrm{X} 21$, $\mathrm{X} 25, \mathrm{X} 26, \mathrm{X} 28$, dan X29.

2. Berdasarkan hasil analisis Gap 5 terdapat 12 variabel kualitas pelayanan jasa pelabuhan yang memiliki kesenjangan antara harapan konsumen dengan persepsi konsumen, yaitu pada variabel 
$\mathrm{X} 3, \mathrm{X} 4, \mathrm{X} 10, \mathrm{X} 11, \mathrm{X} 12, \mathrm{X} 15, \mathrm{X} 17, \mathrm{X} 18$, $\mathrm{X} 25, \mathrm{X} 27$, dan X28.

3. Berdasarkan hasil analisis Gap 1 terdapat 7 variabel kualitas pelayanan jasa pelabuhan yang memiliki kesenjangan antara harapan konsumen dengan persepsi manajemen, yaitu pada variabel $\mathrm{X} 1, \mathrm{X} 3, \mathrm{X} 4, \mathrm{X} 6, \mathrm{X} 8, \mathrm{X} 15$, dan X16.

4. Dari sejumlah atribut yang memiliki kesenjangan baik pada gap 1 maupun gap 5 secara keseluruhan masih banyak atribut yang memiliki kesenjangan positif, artinya bahwa konsumen pada dasarnya sudah lebih banyak mendapatkan kepuasan dari apa yang diterimanya berkaitan dengan sistem pelayanan pada pelayanan jasa Pelabuhan Cigading.

5. Hasil perhitungan memberikan nilai ratarata indeks kepuasan konsumen (customer satisfaction index) sebesar 95.27\%. Hal ini menunjukkan bahwa tingkat pelayanan yang telah diberikan PT. Krakatau Bandar Samudera sebagai

\section{JMTS|}

pengelola Pelabuhan Cigading sudah cukup baik.

\section{REFERENSI}

[1] Kramadibrata S. (2002), Perencanaan Pelabuhan, Institut Teknologi Bandung, Bandung.

[2] Manheim Marvin L. (1979), Fundamentals of Transportation Systems Analysis. Volume 1: Basic Concepts, The MIT Press, Cambridge.

[3] Kotler Philip (1997), Gary Amstrong, Dasar-Dasar Pemasaran, Jilid 1, Prenhallindo, Jakarta.

[4] Parasuraman, A.; Valerie, A.; and Berry, L., 1985. "A Conceptual Model of Service Quality and Its Implications for Future Research," Journal of Marketing, Vol.49, pp.41-50.

[5] Parasuraman, A., Zeithaml, V.A. and Berry, L.L. (1988), SERVQUAL: A Multiple Item Scale for Measuring Consumer Perceptions of Service Quality, Journal of Retailing, Vol. 64, No. 1, pp. $14-40$.

\section{LAMPIRAN}

Nilai Customer Satisfaction Index berdasarkan Gap 5 dan Gap 1 


\begin{tabular}{|c|c|c|c|c|c|}
\hline \multirow{2}{*}{$\begin{array}{c}\text { Dimensi Kualitas } \\
\text { Jasa } \\
\end{array}$} & \multirow{2}{*}{$\begin{array}{c}\text { Atribut } \\
\text { Pelayanan } \\
\end{array}$} & \multirow{2}{*}{ Deskripsi Atribut Pelayanan } & \multicolumn{2}{|c|}{ Nilai } & \multirow{2}{*}{ CSI (\%) } \\
\hline & & & Gap 5 & Gap 1 & \\
\hline \multirow{16}{*}{$\begin{array}{l}\text { Bukti Nyata } \\
\text { (Tangibles) }\end{array}$} & $\mathrm{x} 1$ & Ketersediaan sistem informasi terpadu untuk pembuatan PPJ & 0.006 & -0.027 & 106.97 \\
\hline & $\mathrm{x} 2$ & Ketersediaan alur masuk pelabuhan dan sistem sarana navigasi pelayaran & 0.006 & 0.004 & 106.97 \\
\hline & $\mathrm{x} 3$ & Ketersediaan penerangan yang cukup di area pelabuhan & -0.035 & -0.016 & 56.68 \\
\hline & $\mathrm{x} 4$ & Kebersihan dan keasrian yang terjaga di sektar dermaga & -0.041 & -0.035 & 49.07 \\
\hline & $\mathrm{x} 5$ & Ketersediaan kedalaman laut yang memadai untuk bersandarnya kapal besar & 0.006 & 0.004 & 106.97 \\
\hline & $\mathrm{x} 6$ & Ketersediaan tambatan yang memadai untuk bersandarnya kapal & 0.006 & -0.035 & 106.97 \\
\hline & $\mathrm{x} 7$ & Ketersediaan kapal pandu seperti tugboat untuk melakukan ship handling & 0.000 & 0.000 & 100.00 \\
\hline & $\mathrm{x} 8$ & Kondisi alat bongkar muat (crane, grabber, ship unloader, dsb.) yang handal & 0.006 & -0.016 & 106.97 \\
\hline & $\mathrm{x} 9$ & Ketersediaan area parkir kendaraan bongkar muat barang di pelabuhan yang luas & 0.006 & 0.004 & 106.97 \\
\hline & $\mathrm{x} 10$ & Jumlah personil bagging yang cukup & -0.037 & 0.024 & 39.56 \\
\hline & $\mathrm{x} 11$ & Ketersediaan rambu-rambu di area pelabuhan & -0.046 & 0.000 & 42.99 \\
\hline & $\mathrm{x} 12$ & Ketersediaan sistem keamanan pelabuhan yang canggih dan modern & -0.046 & 0.004 & 42.99 \\
\hline & $\mathrm{x} 13$ & Ketersediaan aksesibilitas (jaringan transportasi) ke pengangkutan darat & 0.006 & 0.004 & 106.97 \\
\hline & $\mathrm{x} 14$ & Kondisi gudang tertutup yang bersih dan terlindung dari cuaca & 0.025 & 0.024 & 140.75 \\
\hline & $\mathrm{x} 15$ & Ketersediaan penerangan lingkungan gudang yang cukup & -0.027 & -0.016 & 66.74 \\
\hline & $\mathrm{x} 16$ & Ketersediaan gudang dan kawasan yang luas & 0.006 & -0.027 & 106.97 \\
\hline \multirow{7}{*}{$\begin{array}{c}\text { Keandalan } \\
\text { (Realiability) }\end{array}$} & $\mathrm{x} 17$ & Kemudahan transaksi (pembuatan PPJ) & -0.007 & 0.024 & 87.81 \\
\hline & $\mathrm{x} 18$ & Penetapan perkiraan waktu yang diperlukan sampainya barang ke konsumen & -0.027 & 0.000 & 66.74 \\
\hline & $\mathrm{x} 19$ & Pengaturan dan pengarsipan data yang baik & 0.006 & 0.004 & 106.97 \\
\hline & $\mathrm{x} 20$ & Kemampuan prasrana pelabuhan untuk jaringan pelayaran dalam dan luar negeri & 0.036 & 0.034 & 171.45 \\
\hline & $\mathrm{x} 21$ & Kecepatan waktu bongkar muat barang yang tinggi & 0.006 & 0.004 & 106.97 \\
\hline & $\mathrm{x} 22$ & Penanganan cleaning tumpahan barang curah untuk mengurangi susut & 0.004 & 0.003 & 106.97 \\
\hline & $\mathrm{x} 23$ & Kemampuan melakukan kalibrasi alat timbangan sebelum dilakukan penimbangan & 0.025 & 0.024 & 140.75 \\
\hline \multirow{2}{*}{\begin{tabular}{|c|} 
Daya Tanggap \\
(Responsiveness)
\end{tabular}} & $\mathrm{x} 24$ & Kecepatan dalam menanggapi keluhan yang disampaikan pelanggan & 0.025 & 0.024 & 140.75 \\
\hline & $\mathrm{x} 25$ & Penerbitan invoice (tagihan) yang relatif cepat & -0.041 & 0.004 & 49.07 \\
\hline \multirow{3}{*}{$\begin{array}{c}\text { Jaminan } \\
\text { (Assurance) }\end{array}$} & $\mathrm{x} 26$ & Ketersediaan SDM yang memiliki kemampuan kerja yang handal & 0.006 & 0.004 & 106.97 \\
\hline & $\mathrm{x} 27$ & Jaminan terhadap resiko kecelakaan kapal yang berlabuh & -0.022 & 0.024 & 64.56 \\
\hline & $\mathrm{x} 28$ & Jaminan keamanan barang mulai dari dermaga sampai gudang tujuan & -0.027 & 0.004 & 66.74 \\
\hline \multirow{2}{*}{$\begin{array}{c}\text { Empati } \\
\text { (Empathy) }\end{array}$} & $\mathrm{x} 29$ & Keramahan dan kesopanan sikap pelayanan staf administrasi & 0.006 & 0.004 & 106.97 \\
\hline & $\mathrm{x} 30$ & Koordinasi yang baik antara staf administrasi dengan customer & 0.025 & 0.024 & 140.75 \\
\hline \multicolumn{5}{|c|}{ Customer Satisfaction Index } & 95.27 \\
\hline
\end{tabular}

